\title{
PENGARUH PEMBELAJARAN BERBASIS MASALAH TERHADAP KECEMASAN DAN KEMAMPUAN PEMODELAN MATEMATIKA
}

\author{
Reppy Erpina ${ }^{1}$, Ely Susanti ${ }^{2}$, Cecil Hiltrimartin ${ }^{3}$ \\ 1) 2) 3) Mahasiswi Universitas Sriwijaya \\ Email: reppyerpina@gmail.com
}

\begin{abstract}
ABSTRAK
Penelitian ini merupakan penelitian jenis eksperimen, yang bertujuan untuk mengetahui pengaruh PBM terhadap kecemasan dan kemampuan pemodelan matematika serta untuk mengetahui hubungan antara kecemasan dan kemampuan pemodelan matematika. Instrumen yang digunakan dalam penelitian ini adalah tes dan angket kecemasan.Tes yang digunakan adalah soal uraian, sedangkan angket kecemasan matematika terdiri dari pernyataan-pernyataan mengenai segala hal yang berhubungan dengan pembelajaran matematika. Berdasarkan analisis data dengan menggunakan uji-t, gain kemampuan pemodelan matematika siswa yang memperoleh Pembelajaran Berbasis Masalah lebih tinggi daripada siswa yang memperoleh pembelajaran matematika dengan model Konvensional. Dari hasil angket yang diberikan, didapat bahwa gain kecemasan matematika siswa yang memperoleh Pembelajaran Berbasis Masalah tidak lebih rendah daripada siswa yang memperoleh pembelajaran matematika dengan model Konvensional. Sedangkan berdasarkan analisis data dengan uji korelasi product moment, bahwa tidak ada hubungan antara kecemasan dan kemampuan pemodelan matematika siswa.
\end{abstract}

Kata kunci : kecemasan, pembelajaran berbasis masalah, pemodelan.

\section{PENDAHULUAN}

Hasil belajar matematika peserta didik di Indonesia masih sangat rendah. Berdasarkan data UNESCO, mutu pendidikan matematika di Indonesia berada pada peringkat 34 dari 38 negara yang diamati. Data lain yang menunjukkan rendahnya prestasi matematika siswa Indonesia dapat dilihat dari hasil survei Pusat Statistik Internasional untuk Pendidikan (National Center for Education in Statistics, 2003) terhadap 41 negara dalam pembelajaran matematika, dimana Indonesia mendapatkan peringkat ke 39 di bawah Thailand dan Uruguay.

Rendahnya hasil belajar siswa dalam pembelajaran matematika ini dipengaruhi oleh banyak hal. Berdasarkan fakta di lapangan, matematika merupakan mata pelajaran yang dianggap sulit oleh siswa di setiap jenjang pendidikan (Yuliana,2007). Penyebab kesulitan tersebut bisa berasal dari dalam diri siswa (internal) dan dari luar diri siswa (eksternal). Salah satu faktor yang berasal dari dalam diri siswa adalah faktor emosi yang dapat dilihat dari sikap siswa terhadap matematika. Siswa yang mengalami hambatan pemenuhan emosi, dapat mengalami kecemasan terhadap matematika. 
Kecemasan siswa terhadap matematika ini dikenal dengan sebutan Mathematics Anxiety.

Pradeep (2011) mengatakan kecemasan matematika ialah perasaan cemas yang dimiliki seseorang terhadap kemampuannya dalam mengerti dan menyelesaikan permasalahan matematika, rasa takut atau tidak suka terhadap matematika, sikap dan perasaan negatif tentang matematika serta rasa takut akan kegagalan dalam tes matematika. Sedangkan menurut Yosef (2009) kecemasan terhadap matematika merupakan bentuk respon emosional saat pelajaran matematika, mendengarkan guru, saat mengerjakan permasalahan matematika, dan mendiskusikan matematika.

Seperti yang dituliskan oleh Zakaria \& Nordin (2007) bahwa ada hubungan antara kecemasan matematika dengan prestasi siswa dalam matematika. Hal ini sejalan dengan pernyataan guru matematika di SMA Negeri 1 Indralaya Utara, Bapak Fachruddin mengatakan bahwa pelajaran yang paling dihindari oleh sebagian besar siswa di sekolah adalah matematika. Menurut pengamatan, siswa - siswa yang diduga mengalami kecemasan dalam matematika cenderung akan mencari - cari alasan untuk tidak mengikuti pelajaran matematika. Sedangkan berdasarkan hasil ulangan harian beberapa kelas di SMA Negeri 1 Indralaya Utara, lebih dari 50\% siswa mengalami kesalahan dalam menyelesaikan soal - soal atau permasalahan matematika yang diberikan oleh guru. Sebagian besar kesalahan yang dilakukan siswa terletak pada proses menerjemahkan soal kedalam model matematika, seperti membuat pengandaian dalam bentuk simbol matematika dan membentuk persamaan dari pengandaian tersebut sesuai dengan pertanyaan yang diberikan.

Maka dari itu, perlu dicari suatu solusi yang mampu mengurangi kecemasan siswa terhadap matematika, sehingga dapat meningkatkan prestasi belajar siswa pada pembelajaran matematika khususnya pada proses membentuk model matematika yang merupakan salah satu kunci utama untuk siswa mampu menyelesaikan permasalahan matematika. Dalam pemodelan matematika, siswa dituntut mempunyai kemampuan untuk memahami dan mencerna bahasa yang digunakan dalam soal tersebut menjadi model matematika. Ketika siswa mampu menerjemahkan soal kedalam model matematika, selanjutnya siswa diharapkan mampu menyelesaikan masalah tersebut.

Adapun menurut Peker (2009) faktor yang menjadi penyebab kecemasan siswa terhadap matematika diklasifikasikan kedalam tiga kategori yaitu faktor kepribadian, faktor lingkungan/sosial dan faktor intelektual. Terlihat bahwa dua dari ketiga faktor yang dapat berpengaruh pada kecemasan matematika siswa merupakan faktor yang 
timbul dari dalam dirinya sendiri, yaitu faktor kepribadian dan faktor intelektual. Sedangkan peran lingkungan atau sosial merupakan faktor dari luar diri siswa, yang dapat berpengaruh besar pada kecemasan siswa terhadap matematika. Faktor lingkungan atau sosial, misalnya kondisi saat proses belajar mengajar matematika di kelas yang tegang diakibatkan oleh cara mengajar, model dan metode mengajar guru matematika (Wahyudin, 2010). Inilah mengapa peran guru dan metode pembelajaran di dalam kelas menjadi hal yang perlu diperhatikan, karena sebagian besar waktu siswa di habiskan disekolah.

Menurut Pradeep (2012) ada beberapa teknik mengajar guru yang dapat membuat siswa mengalami kecemasan terhadap matematika, yakni pembelajaran yang berpusat pada guru seperti ceramah, memberikan tugas yang sama kepada seluruh siswa, terlalu berpatok pada buku, memberika pekerjaan rumah setiap hari, menekankan hanya pada satu jawaban, menugaskan pekerjaan rumah matematika sebagai hukuman karena nakal, hanya mengajarkan rumus dan aturan matematika. Dikatakan juga bahwa guru lebih banyak diam di satu tempat daripada berkeliling saat mengajar, menetapkan pekerjaan yang sama untuk semua siswa dan jarang mengajarkan teknik dan strategi pemecahan masalah (lih, Gresham, 2008).

Oleh karena itu, berdasarkan uraian diatas guru dituntut untuk dapat memilih model pembelajaran yang tepat sehingga dapat mengurangi kecemasan siswa terhadap matematika. Salah satu alternatif pilihan yang dapat digunakan dalam pembelajaran adalah model problem based learning (PBL) atau pembelajaran berbasis masalah (PBM). Hal yang membuat model pembelajaran berbasis masalah dirasa cocok untuk mengurangi kecemasan siswa terhadap matematika adalah karena langkah pembelajaran yang digunakan. Menurut Rusman (2013) Langkah pembelajaran yang digunakan pada PBM terdiri dari lima fase yakni 1) Orientasi siswa pada masalah; 2) mengorganisasi siswa untuk belajar; 3) membimbing pengalaman individual/kelompok; 4) mengembangkan dan menyajikan hasil karya; dan 5) menganalisis dan mengevaluasi proses pemecahan masalah. Dari kelima fase tersebut terlihat bahwa PBM merupakan pembelajaran yang berpusat pada siswa, tidak hanya mengajarkan rumus dan aturan matematika, dan tidak berpatok pada buku. Selain itu PBM juga tidak menekankan hanya pada satu jawaban yakni pada fase menganalisis dan mengevaluasi proses pemecahan masalah, siswa diberi kebebasan menjawab dengan banyak langkah penyelesaian. 
Selain itu berdasarkan penelitian yang dilakukan oleh Novriansyah (2012) mengenai pengaruh Pembelajaran Berbasis Masalah terhadap kemampuan siswa dalam pemodelan matematika di kelas VII SMP Negeri 18 Palembang, terdapat pengaruh positif Pembelajaran Berbasis Masalah terhadap kemampuan siswa dalam pemodelan matematika yakni ditunjukkan dengan rata-rata nilai posttest mencapai 80,13 yang dikategorikan baik.

Maka dari itu diharapkan dengan penerapan pembelajaran berbasis masalah dapat menekan kecemasan siswa terhadap matematika dan mengembangkan kemampuan siswa dalam pemodelan matematika. Oleh karena itu, peneliti tertarik melakukan penelitian dengan judul "Pengaruh Pembelajaran Berbasis Masalah terhadap Kecemasan dan Kemampuan Pemodelan Matematika".

Berdasarkan uraian yang telah dijelaskan, maka permasalahan umum yang dicari jawabannya melalui penelitian ini adalah sebagai berikut : (1) Apakah kecemasan matematika siswa yang belajar dengan menggunakan Pembelajaran Berbasis Masalah lebih rendah dari siswa yang belajar dengan menggunakan pembelajaran konvensional?, (2) Apakah kemampuan pemodelan matematika siswa yang belajar dengan menggunakan Pembelajaran Berbasis Masalah lebih tinggi dari siswa yang belajar dengan menggunakan pembelajaran konvensional?, (3) Apakah terdapat hubungan yang signifikan antara skor kecemasan matematika (Mathematics Anxiety) dan kemampuan pemodelan matematika?

\section{METODE PENELITIAN}

\section{A. Metode dan desain Penelitian}

Metode yang digunakan dalam penelitian ini adalah Quasi Eksperimen, metode ini digunakan untuk membandingkan kecemasan dan kemampuan pemodelan matematika dua kelompok kelas. Kedua kelompok tersebut ialah kelompok eksperimen yang memperoleh pembelajaran berbasis masalah dan kelompok kontrol yang mendapat pengajaran konvensional. Desain penelitian yang digunakan adalah Nonequivalent Control Group Design.

\section{B. Populasi dan Sampel}

Populasi penelitian ini adalah seluruh siswa kelas X MIPA di SMA Negeri 1 Indralaya Utara tahun pembelajaran 2016/2017. Dalam penelitian ini sampel dipilih dimana kelasnya utuh (intact group), namun diasumsikan bahwa seluruh kelas $\mathrm{X}$ 
MIPA adalah kelas yang homogen. Dengan cara diundi, didapat kelas X MIA 1 sebagai kelas eksperimen dan kelas X MIA 2 sebagai kelas kontrol.

\section{Waktu dan Tempat Penelitian}

Penelitian dilaksanakan di SMA Negeri 1 Indralaya Utara kelas X pada semester ganjil tahun pembelajaran 2016/2017.

\section{Variabel Penelitian}

Variabel menjadi perhatian dalam penelitian ini adalah kecemasan dan kemampuan pemodelan matematika.

\section{E. Definisi Operasional Variabel Penelitian}

Dalam penelitian ini definisi operasional variabelnya adalah :

1. Kecemasan matematika (Mathematics Anxiety) yaitu reaksi emosional berupa perasaan takut, tegang, atau cemas ketika berkaitan dengan matematika, manipulasi angka atau bilangan. Kecemasan matematika diukur menggunakan angket, yang selanjutnya dikonversikan kedalam bentuk skor kecemasan siswa.

2. Kemampuan pemodelan matematika yaitu kemampuan siswa dalam menerjemahkan suatu permasalahan kedalam kalimat matematika (model matematika). Kemampuan pemodelan matematika diukur menggunakan soal soal tes yang berbentuk uraian.

\section{F. Prosedur Penelitian}

Adapun langkah-langkah dalam penelitian ini adalah sebagai berikut:

1. Langkah awal, peneliti menghubungi sekolah yang akan dijadikan tempat penelitian.

2. Menentukan populasi dan sampel penelitian.

3. Menyusun kisi-kisi tes berdasarkan indikator kemampuan pemodelan matematika.

4. Menyusun kisi-kisi angket berdasarkan indikator kecemasan matematika.

5. Menyusun instrumen tes ( soal pretest dan soal posttest) kemampuan pemodelan matematika berdasarkan kisi-kisi yang ada, selanjutnya instrumen tes divalidasi.

6. Menyusun instrumen angket kemampuan pemodelan matematika berdasarkan kisi-kisi yang ada, selanjutnya angket tersebut divalidasi.

7. Memberikan pretest kepada kelas eksperimen dan kelas kontrol. Pretest dilakukan untuk membuktikan bahwa kelas eksperimen dan kelas kontrol berada pada kondisi awal yang sama, yakni memiliki kemampuan pemodelan matematika dan kecemasan matematika yang sama. 
8. Menyusun rencana pelaksanaan pembelajaran menggunakan Pembelajaran Berbasis Masalah.

9. Menerapkan rencana pelaksanaan pembelajaran menggunakan Pembelajaran Berbasis Masalah di kelas X MIA 1.

10. Menerapkan rencana pelaksanaan pembelajaran menggunakan pembelajaran konvensional yakni berupa ceramah, tanya jawab dan pemberian tugas. di kelas X MIA 2.

11. Melaksanakan tes akhir berupa tes kemampuan pemodelan matematika dan pemberian angket kecemasan matematika (Mathematic Anxiety) pada kelas eksperimen dan kelas kontrol.

12. Menganalisis data hasil tes, menarik kesimpulan dan menyusun hasil penelitian.

\section{G. Teknik Pengumpulan Data}

Tes diberikan untuk mengetahui kemampuan siswa dalam pemodelan matematika, tes dilakukan sebelum pembelajaran (Pretest) dan setelah pembelajaran (posttest). Tes (pretest dan posttest) yang diberikan berupa tes uraian tertulis yang berbentuk soal cerita yang masing - masing terdiri dari tiga soal. Sebelum melaksanakan tes, soal yang akan digunakan dikonsultasikan terlebih dahulu dengan dosen matematika dan guru matematika. Selanjutnya dilakukan uji coba, kemudian dilakukan uji validitas, reliabilitas, daya pembeda dan tingkat kesukaran soal.

Sedangkan untuk untuk mengetahui tingkat kecemasan siswa terhadap matematika digunakan angket, angket diberikan sebelum pembelajaran dan setelah pembelajaran. Instrumen menggunakan skala Likert dengan lima alternatif tanggapan yaitu : Sangat Sering (SS), Sering (S), Kadang - kadang (KK) Jarang (J) dan Tidak Pernah (TP) . Sebelum digunakan angket diuji validitas dan reliabilitasnya terlebih dahulu. Setelah itu digunakan wawancara untuk memperoleh data tambahan atau informasi lebih lanjut guna memperkuat jawaban siswa pada angket kecemasan matematika.

\section{H. Teknik Analisa Data}

1. Analisis Data Tes Kemampuan Pemodelan Matematika

Dari setiap langkah penyelesaian soal yang diberikan baik pretest maupun posttest, ada tahap-tahap yang harus dikuasai oleh siswa yang selanjutnya dari tahaptahap tersebut dikelompokkan menjadi indikator kemampuan siswa dalam pemodelan matematika. Indikator-indikator tersebut menjadi kriteria dalam pedoman penskoran, 
hal ini dilakukan untuk memperoleh data kemampuan siswa dalam pemodelan matematika.

Tabel 1. Pedoman Penskoran Soal Tes

\begin{tabular}{|c|c|c|c|}
\hline $\begin{array}{c}\text { Kemampuan yang } \\
\text { diukur }\end{array}$ & Aspek yang dinilai & Skor & Rubrik \\
\hline \multirow[t]{2}{*}{$\begin{array}{l}\text { Mengidentifikasi } \\
\text { masalah }\end{array}$} & $\begin{array}{l}\text { Dapat menuliskan apa yang } \\
\text { diketahui dari soal }\end{array}$ & 1 & $\begin{array}{l}\text { Skor } 0 \text { jika sama sekali } \\
\text { tidak menjawab }\end{array}$ \\
\hline & $\begin{array}{l}\text { Dapat menuliskan apa yang } \\
\text { ditanya }\end{array}$ & 1 & $\begin{array}{l}\text { Skor } 0 \text { jika sama sekali } \\
\text { tidak menjawab }\end{array}$ \\
\hline \multirow{3}{*}{$\begin{array}{l}\text { Membuat } \\
\text { pengandaian }\end{array}$} & \multirow{3}{*}{$\begin{array}{l}\text { Dapat memisalkan unsur yang } \\
\text { diketahui kedalam bentuk } \\
\text { variabel }\end{array}$} & \multirow{3}{*}{3} & $\begin{array}{l}\text { Skor } 0 \text { jika sama sekali } \\
\text { tidak menjawab }\end{array}$ \\
\hline & & & $\begin{array}{l}\text { Skor } 1 \text { jika menjawab } \\
\text { tetapi salah }\end{array}$ \\
\hline & & & $\begin{array}{l}\text { Skor } 2 \text { jika menjawab } \\
\text { dengan kurang } \\
\text { tepat/lengkap }\end{array}$ \\
\hline \multirow{4}{*}{$\begin{array}{l}\text { Merumuskan } \\
\text { persamaan }\end{array}$} & \multirow{4}{*}{$\begin{array}{l}\text { Dapat menyusun pemisalan } \\
\text { yang telah dibuat dalam } \\
\text { bentuk variabel kedalam } \\
\text { model matematika }\end{array}$} & \multirow{4}{*}{4} & $\begin{array}{l}\text { Skor } 0 \text { jika sama sekali } \\
\text { tidak menjawab }\end{array}$ \\
\hline & & & $\begin{array}{l}\text { Skor } 1 \text { jika menjawab } \\
\text { tetapi salah }\end{array}$ \\
\hline & & & $\begin{array}{l}\text { Skor } 2 \text { jika menjawab } \\
\text { tetapi benar sebagian }\end{array}$ \\
\hline & & & $\begin{array}{l}\text { Skor } 3 \text { jika menjawab } \\
\text { dengan kurang lengkap }\end{array}$ \\
\hline \multirow{4}{*}{$\begin{array}{l}\text { Menyelesaikan } \\
\text { persamaan }\end{array}$} & \multirow{4}{*}{$\begin{array}{l}\text { Dapat menyederhanakan } \\
\text { model matematika }\end{array}$} & \multirow{4}{*}{4} & $\begin{array}{l}\text { Skor } 0 \text { jika sama sekali } \\
\text { tidak menulis }\end{array}$ \\
\hline & & & $\begin{array}{l}\text { Skor } 1 \text { jika menulis tetapi } \\
\text { salah }\end{array}$ \\
\hline & & & $\begin{array}{l}\text { Skor } 2 \text { jika menjawab } \\
\text { tetapi benar sebagian }\end{array}$ \\
\hline & & & $\begin{array}{l}\text { Skor } 3 \text { jika benar } \\
\text { sebagian }\end{array}$ \\
\hline $\begin{array}{l}\text { Menafsirkan } \\
\text { solusi }\end{array}$ & $\begin{array}{l}\text { Dapat menentukan jawaban } \\
\text { dari penyelesaian yang dibuat. }\end{array}$ & 1 & $\begin{array}{l}\text { Skor } 0 \text { jika sama sekali } \\
\text { tidak menulis }\end{array}$ \\
\hline \multirow{2}{*}{$\begin{array}{l}\text { Membandingkan } \\
\text { dengan data yang } \\
\text { ada }\end{array}$} & $\begin{array}{l}\text { Dapat menentukan apakah } \\
\text { solusi yang didapat telah } \\
\text { sesuai dengan fakta yang ada. }\end{array}$ & 1 & $\begin{array}{l}\text { Skor } 0 \text { jika sama sekali } \\
\text { tidak menulis }\end{array}$ \\
\hline & Skor maksimum & 15 & \\
\hline
\end{tabular}

(Sumber: Novriansyah, Tahun: 2012)

2. Analisis Data Angket Kecemasan Matematika 
Histogram: Jurnal Pendidikan Matematika, Volume 1 Nomor 2, September 2017, pp 100-114

Dalam pemberian skor pada angket digunakan skala Likert dengan rentang 1-5, yakni terdapat lima alternatif tanggapan yaitu : Sangat Sering (SS), Sering (S), Kadang - kadang (KK) Jarang (J) dan Tidak Pernah (TP). Pernyataan - pernyataan yang diberikan berbentuk pernyataan positif dan negatif, Kriteria penyekorannya adalah sebagai berikut:

Tabel 2 Tabel Kriteria Penyekoran Angket Kecemasan Matematika Siswa:

\begin{tabular}{ccc}
\hline Alternatif Jawaban & Pernyataan Positif & Pernyataan Negatif \\
\hline Sangat Sering & 1 & 5 \\
\hline Sering & 2 & 4 \\
\hline Kadang-kadang & 3 & 3 \\
\hline Jarang & 4 & 2 \\
\hline Tidak Pernah & 5 & 1 \\
\hline
\end{tabular}

3. Analisis Wawancara

Data yang diperoleh dari hasil wawancara dianalisis dengan langkah sebagai berikut.

1. Mengubah hasil wawancara dari bentuk lisan ke bentuk tulisan.

2. Menganalisis jawaban hasil wawancara

\section{HASIL DAN PEMBAHASAN}

Pada penelitian ini, yang ingin dilihat adalah apakah hasil belajar kelas eksperimen yang belajar dengan pembelajaran berbasis masalah lebih baik dari hasil belajar kelas kontrol. Dan apakah kecemasan matematika siswa kelas eksperimen menjadi lebih rendah dari kelas kontrol setelah diberikan pembelajaran berbasis masalah. Untuk melakukan pengujian statistik terhadap data kecemasan dan kemampuan pemodelan matematika digunakanlah data gain yang telah dinormalisasikan ( $N$-Gain). Berdasarkan data pretest dan posttest, didapat hasil perhitungan nilai rata-rata dan simpangan baku $N$-gain kemampuan pemodelan matematika dan kecemasan matematika sebagai berikut

Tabel 2. Rekapitulasi Data N-Gain Kemampuan Pemodelan dan Kecemasan

Matematika

\begin{tabular}{ccccccc}
\hline & \multicolumn{3}{c}{ Kemampuan Pemodelan } & \multicolumn{3}{c}{ Kecemasan Matematika } \\
\hline Kelas & $\bar{x}$ & $S$ & $n$ & $\bar{x}$ & $S$ & $n$ \\
\hline Eksperimen & 0,47 & 0,21 & 30 & $-0,0443$ & 0,1480 & 30 \\
\hline Kontrol & 0,35 & 0,18 & 32 & $-0,0367$ & 0,2300 & 32 \\
\hline
\end{tabular}

(Sumber: Data Primer, Tahun: 2017)

Untuk mengetahui gain kemampuan pemodelan matematika pembelajaran mana yang lebih baik dan kecemasan matematika kelas mana yang lebih rendah, perlu 
dilakukan uji perbedaan rata-rata. Sebelum dilakukan uji perbedaan rata-rata, dilakukan uji normalitas dan uji homogenitas varian dua kelompok data untuk menentukan uji statistik yang sesuai.

Uji normalitas skor $N$-gain kemampuan pemodelan matematika dan kecemasan matematika dapat dilihat pada tabel berikut.

Tabel 3. Uji Normalitas Data N-Gain Kemampuan Pemodelan dan Kecemasan Matematika

\begin{tabular}{ccccccc}
\hline & \multicolumn{3}{c}{ Kemampuan Pemodelan } & \multicolumn{3}{c}{ Kecemasan Matematika } \\
\hline Kelas & $\mathbf{L}_{\text {hitung }}$ & $\mathbf{L}_{\text {tabel }}$ & $\mathbf{H}_{\mathbf{0}}$ & $\mathbf{L}_{\text {hitung }}$ & $\mathbf{L}_{\text {tabel }}$ & $\mathbf{H}_{\mathbf{0}}$ \\
\hline Eksperimen & $\mathbf{0 , 1 2 3 6}$ & $\mathbf{0 , 1 6 1 7}$ & Terima & $\mathbf{0 , 1 4 3 5}$ & $\mathbf{0 , 1 6 1 7}$ & Terima \\
\hline Kontrol & $\mathbf{0 , 1 0 0 3}$ & $\mathbf{0 , 1 5 6 6}$ & Terima & $\mathbf{0 , 1 5 4 5}$ & $\mathbf{0 , 1 5 6 6}$ & Terima \\
\hline
\end{tabular}

(Sumber: Data Primer, Tahun: 2017)

Berdasarkan uji normalitas di atas terlihat bahwa baik kelas eksperimen maupun kelas kontrol, nilai $\mathrm{L}_{\text {hitung }}<\mathrm{L}_{\text {tabel }}$. Ini berarti $\mathrm{H}_{0}$ diterima, dan disimpulkan bahwa nilai gain kemampuan pemodelan dan kecemasan matematika kelas eksperimen dan kelas kontrol berdistribusi normal. Selanjutnya dilakukan uji homogenitas terhadap nilai gain kemampuan pemodelan dan kecemasan matematika siswa kelas eksperimen dan kelas kontrol, pengujian homogenitas diuji menggunakan Uji F.

Uji homogenitas data gain kemampuan pemodelan dan kecemasan matematika disajikan pada tabel berikut.

Tabel 4. Uji Homogenitas N-Gain Kemampuan Pemodelan dan Kecemasan

Matematika :

\begin{tabular}{cccccc}
\hline \multicolumn{3}{c}{ Kemampuan Pemodelan } & \multicolumn{3}{c}{ Kecemasan Matematika } \\
\hline $\mathbf{F}_{\text {hitung }}$ & $\mathbf{F}_{\text {tabel }}$ & $\mathbf{H}_{\mathbf{0}}$ & $\mathbf{F}_{\text {hitung }}$ & $\mathbf{F}_{\text {tabel }}$ & $\mathbf{H}_{\mathbf{0}}$ \\
\hline 1,3176 & 1,8349 & Terima & 2,4133 & 1,8481 & Tolak \\
\hline
\end{tabular}

(Sumber: Data Primer, Tahun: 2017)

Berdasarkan tabel diatas, untuk kemampuan pemodelan matematika diperoleh nilai $\mathrm{F}_{\text {hitung }}<\mathrm{F}_{\text {tabel }}$ sehingga $\mathrm{H}_{0}$ diterima. Artinya tidak terdapat perbedaan varian (variannya homogen) antara kedua data kelompok tersebut, yakni antara gain kemampuan pemodelan matematika kelas eksperimen dan kelas kontrol. Selanjutnya karena data kedua kelas terbukti normal dan homogen, maka untuk mengetahui apakah gain kemampuan pemodelan matematika siswa yang mendapat pembelajaran berbasis masalah lebih baik daripada siswa yang mendapat pembelajaran konvensional dilakukan uji-t. Sedangkan untuk kecemasan matematika diperoleh nilai $F_{\text {hitung }}>F_{\text {tabel }}$ sehingga $\mathrm{H}_{0}$ ditolak. Artinya terdapat perbedaan varian (variannya tidak homogen) antara kedua data kelompok tersebut, yakni antara skor gain kecemasan matematika 
kelas eksperimen dan kelas kontrol. Selanjutnya dilakukan uji perbedaan rata-rata untuk mengetahui apakah skor gain kecemasan matematika siswa yang mendapat pembelajaran berbasis masalah lebih rendah daripada siswa yang mendapat pembelajaran konvensional dengan uji-t'.

Hasil uji perbedaan rata-rata data gain kemampuan pemodelan matematika selengkapnya dapat dilihat pada lampiran dan ringkasan uji perbedaan rata-rata dapat dilihat pada tabel berikut.

Tabel 5. Hasil Uji Perbedaan Rata-rata $N$-Gain Kemampuan Pemodelan dan Kecemasan Matematika:

\begin{tabular}{cccccc}
\hline \multicolumn{2}{c}{ Kemampuan Pemodelan } & \multicolumn{3}{c}{ Kecemasan Matematika } \\
\hline $\mathbf{t}_{\text {hitung }}$ & $\mathbf{t}_{\text {tabel }}$ & $\mathbf{H}_{\mathbf{0}}$ & $\mathbf{t}_{\text {hitung }}$ & $\mathbf{t}_{\text {tabel }}$ & $\mathbf{H}_{\mathbf{0}}$ \\
\hline 2,2824 & 2,0003 & Tolak & 0,1536 & 2,0003 & Terima \\
\hline
\end{tabular}

(Sumber: Data Primer, Tahun: 2017)

Berdasarkan hasil uji perbedaan rata-rata data $\mathrm{N}$-gain kemampuan pemodelan matematika yang disajikan pada tabel $5 \mathrm{di}$ atas, diperoleh bahwa nilai jika $t_{\text {hitung }}>t_{\text {tabel }}$ sehingga $\mathrm{H}_{0}$ ditolak. Ini berarti rata-rata nilai $N$-Gain kemampuan pemodelan matematika siswa kelas eksperimen lebih dari kelas kontrol, atau rata-rata nilai $\mathrm{N}$-gain kemampuan pemodelan matematika siswa yang mendapatkan pembelajaran berbasis masalah lebih baik dari siswa yang mendapat pembelajaran konvensional. Hal ini sesuai dengan hipotesis yang diajukan sebelumnya dan menunjukkan bahwa pembelajaran dengan PBL mendukung dan mampu memfasilitasi dalam pencapaian kemampuan pemodelan matematika siswa. Hasil penelitian ini sama halnya dengan temuan dari penelitian Novriansyah (2012) yang menyatakan bahwa pembelajaran berbasis masalah memiliki pengaruh positif terhadap kemampuan pemodelan matematika.

Sedangkan berdasarkan hasil uji perbedaan rata-rata data skor gain kecemasan matematika di atas, diperoleh bahwa nilai $t_{\text {hitung }}<t_{\text {tabel }}$ sehingga $\mathrm{H}_{0}$ diterima. Ini berarti rata-rata nilai gain kecemasan matematika siswa kelas eksperimen tidak lebih rendah dari dari kelas kontrol.

Alasan ketidak tercapaian hasil yang optimal pada kecemasan matematika antara lain berkaitan dengan pelaksanaan pembelajaran yang kurang optimal. Serta telah dijelaskan sebelumnya bahwa ada beberapa teknik mengajar guru yang dapat menggiring siswa untuk mengalami kecemasan terhadap matematika, yakni berpusat pada guru seperti ceramah, memberikan tugas yang sama kepada seluruh siswa, terlalu 
berpatok pada buku, memberika pekerjaan rumah setiap hari, menekankan hanya pada satu jawaban, fokus hanya pada keseluruhan kelas, hanya mengajarkan rumus dan aturan matematika. Dari penjelasan diatas,terlihat bahwa masih ada hal-hal yang dilakukan pada saat pembelajaran berbasis masalah yang membuat siswa merasa cemas. Salah satunya memberika pekerjaan rumah setiap hari yang dilakukan guru sebagai latihan karena kurang optimalnya pembelajaran di dalam kelas.

Alasan lain adalah waktu pembelajaran yang terlalu singkat untuk dapat mengubah perasaan cemas siswa menjadi semakin rendah yakni hanya tiga kali pertemuan. Pasalnya untuk dapat menekan kecemasan siswa terhadap matematika diperlukan setidaknya waktu yang cukup lama, seperti penelitian yang dilakukan oleh Rusmono (2009) dan penelitian yang dilakukan oleh Pradeep (2011) yakni sekitar tiga bulan. Selain itu, faktor lain yang dapat mempengaruhi kecemasan matematika siswa selain PBL adalah faktor kepribadian dan faktor intelektual. Kedua faktor ini menjadi salah satu alasan ketidakmaksimalan penurunan kecemasan matematika pada seorang siswa setelah belajar dengan pembelajaran berbasis masalah. Kurangnya motivasi diri dan tingkat kecerdasan siswa yang memang rendah inilah yang menghambat penurunan kecemasan matematika siswa walaupun telah belajar dengan model pembelajaran yang baik seperti PBL.

Selanjutnya untuk mengetahui apakah terdapat hubungan yang signifikan antara kecemasan matematika dan kemampuan pemodelan matematika siswa, dilakukan pengujian korelasi terhadap nilai posttest kemampuan pemodelan matematika dan kecemasan matematika baik kelas eksperimen maupun kelas kontrol. Namun sebelum dilakukan pengujian korelasi, terlebih dahulu dilakukan uji normalitas terhadap kedua kelompok data, uji normalitas dapat dilihat pada tabel berikut.

Tabel 6. Uji Normalitas Data $N$-Gain Kemampuan Pemodelan dan Kecemasan Matematika Kelas eksperimen dan Kelas Kontrol :

\begin{tabular}{cccc}
\hline & $\mathbf{L}_{\text {hitung }}$ & $\mathbf{L}_{\text {tabel }}$ & $\mathbf{H}_{\mathbf{o}}$ \\
\hline Kemampuan Pemodelan & 0,0606 & 0,1116 & Terima \\
\hline Kecemasan Matematika & 0,0673 & 0,1116 & Terima \\
\hline
\end{tabular}

(Sumber: Data Primer, Tahun: 2017)

Berdasarkan uji normalitas di atas terlihat bahwa kedua kelompok data memiliki nilai $\mathrm{L}_{\text {hitung }}<\mathrm{L}_{\text {tabel. }}$ Ini berarti $\mathrm{H}_{0}$ diterima, dan disimpulkan bahwa data kemampuan pemodelan matematika dan kecemasan matematika siswa kelas eksperimen dan kelas kontrol berdistribusi normal. Karena kedua data berdistribusi normal, maka untuk menguji korelasi kedua kelompok data tersebut digunakan uji 
Histogram: Jurnal Pendidikan Matematika, Volume 1 Nomor 2, September 2017, pp 100-114

korelasi product moment. $\quad$ Uji korelasi product moment dapat dilihat pada tabel berikut.

Tabel 7. Uji Korelasi N-Gain Kemampuan Pemodelan dan Kecemasan Matematika :

\begin{tabular}{ccc}
\hline $\mathbf{r}_{\text {hitung }}$ & $\mathbf{r}_{\text {tabel }}$ & $\mathbf{H}_{\mathbf{0}}$ \\
\hline 0,0966 & 0,2461 & Terima \\
\hline
\end{tabular}

(Sumber: Data Primer, Tahun: 2017)

Berdasarkan hasil uji korelasi product moment antara kemampuan pemodelan matematika dan kecemasan matematika siswa yang disajikan pada tabel 7 di atas, diperoleh bahwa nilai $r_{\text {hitung }}<r_{\text {tabel }}$ sehingga $\mathrm{H}_{0}$ diterima. Ini berarti tidak terdapat hubungan yang signifikan antara skor kecemasan matematika (Mathematics Anxiety) dan kemampuan pemodelan matematika.

Sedangkan pada tabel 5 , dapat dilihat nilai $t_{\text {hitung }}$ kurang dari $t_{\text {tabel, }}$, sehingga terima $\mathrm{H}_{0}$ yang artinya tidak terdapat hubungan antara kecemasan matematika dan kemampuan pemodelan matematika. Perhitungan ini dilakukan terhadap gain kemampuan pemodelan matematika dan angket kecemasan matematika. Hal ini tidak sesuai dengan hipotesis yang diharapkan yaitu semakin rendah penurunan kecemasan matematika siswa maka akan semakin tinggi kenaikan kemampuan pemodelan matematikanya.

Dari proses kegiatan yang telah dilakukan, peneliti melihat terdapat beberapa kendala yang megakibatkan kurang maksimalnya peningkatan kemampuan pemodelan matematika siswa dan penurunan kecemasan matematika, antara lain adalah sebagai berikut :

1. Keterbatasan waktu pembelajaran, pada fase mengorganisasikan untuk belajar, banyak waktu yang terbuang. Beberapa kelompok belajar mengalami kesulitan dalam mendefinisikan permasalahan sehingga peneliti berulang kali menjelaskan kepada siswa. Akibat dari banyaknya waktu terbuang, hal ini berpengaruh pada fase mengembangkan dan menyajikan hasil karya serta menganalisis dan mengevaluasi proses, dimana fase ini merupakan fokus yang penting dalam penelitian ini dan diharapkan dapat berpengaruh pada kemampuan pemodelan matematika siswa yakni pada kemampuan menafsir solusi dan looking back. Serta pada fase tersebut diharapkan mampu berpengaruh pada kecemasan matematika siswa.

2. Masih ada siswa yang sungkan untuk berdiskusi dalam kelompoknya, bermalasmalasan dan saling melempar tanggung jawab dalam menuliskan penyelesaian 
pada LKS, serta terdapat beberapa kelompok yang dalam penyelesaian masalahnya didominasi oleh seseorang yang menonjol. Hal ini sejalan dengan penelitian yang dilakukan oleh Suryosubroto (2002) yang mengungkap kelemahan metode diskusi kelompok tersebut.

3. Masih ada siswa tidak melakukan pengecekan kembali pada soal latihan yang diberikan peneliti. Meskipun pada saat pembelajaran dan pada saat pengerjaan latihan siswa telah diminta untuk menuliskan pengecekan kembali namun hal tersebut belum cukup untuk membiasakan siswa untuk melakukan pengecekan kembali secara tertulis baik dalam pencocokkan hasil dengan informasi pada soal; membuktikan jawaban; ataupun menggunakan argumentasi/alasan. siswa lebih terbiasa untuk menuliskan apa yang diketahui dan apa yang ditanyakan serta meyelesaikan solusi secara langsung terlebih lagi masih banyak siswa yang tidak menuliskan pengecekan kembali pada saat menjawab latihan yang diberikan peneliti. Sehingga, pada saat tes kemampuan pemecahan masalah, masih banyak siswa yang kesulitan dan tidak melakukan pengecekan kembali terhadap soal yang diberikan. Hal ini sesuai dengan penelitian yang dilakukan oleh Tias (2015) yang mengatakan bahwa siswa kurang teliti, lupa serta tergesa-gesa dalam mengerjakan soal, sehingga siswa keliru atau tidak sama sekali memeriksa hasil yang diperoleh.

4. Ketiga soal pretest maupun posttest yang diberikan menurut siswa tergolong rumit dan sulit.

5. Salah satu kelemahan dari penelitian ini yaitu, perbedaan guru antara kelas eksperimen dan kelas kontrol yang berpengaruh pada pembelajaran di dalam kelas.

\section{KESIMPULAN DAN SARAN}

\section{A. Kesimpulan}

Berdasarkan hasil penelitian dan pembahasan dari penelitian tentang pengaruh pembelajaran berbasis masalah terhadap kecemasan dan kemampuan pemodelan matematika, dapat dikemukakan beberapa kesimpulan berikut.

1. Kemampuan pemodelan matematika siswa pada pembelajaran matematika menggunakan pembelajaran berbasis masalah lebih baik daripada siswa yang mendapatkan pembelajaran konvensional, dengan rata-rata gain kemampuan pemodelan matematika pada siswa yang memperoleh pembelajaran berbasis 
Histogram: Jurnal Pendidikan Matematika, Volume 1 Nomor 2, September 2017, pp 100-114

masalah mencapai 41,70 dan yang memperoleh pembelajaran konvensional sebesar 31,67 .

2. Siswa yang belajar matematika dengan PBL tidak memiliki kecemasan matematika (Mathematic Anxiety) yang lebih rendah dibandingkan dengan siswa yang memperoleh pembelajaran konvensional.

3. Tidak terdapat hubungan yang signifikan antara kecemasan matematika dan kemampuan pemodelan matematika.

\section{B. Saran}

Dari hasil penelitian yang diperoleh, maka peneliti menyarankan :

1. Guru

Dengan adanya hasil penelitian ini, guru diharapkan mampu menerapkan model pembelajaran berbasis masalah materi matematika lainnya.

2. Sekolah

Agar sekolah dapat memfasilitasi guru dalam membuat atau menggunakan buku/sumber belajar yang dapat mengasah kemampuan pemodelan matematika siswa.

3. Peneliti lain

Bagi peneliti lain, diharapkan dapat melakukan pembelajaran yang akan digunakan dengan lebih baik lagi. Disarankan agar lebih memperhatikan proses pembelajaran saat dikelas, memperhatikan LKS dan soal tes yang diberikan dan perlu melakukan penelitian lebih lanjut pada tingkatan sekolah lain seperti SMK dan SMP. Serta untuk mendapatkan hasil yang maksimal dalam menekan kecemasan siswa terhadap matematika, disarankan agar penelitian dilakukan dalam waktu yang cukup lama dan berkesinambungan.

\section{DAFTAR PUSTAKA}

Ang,K.C.(2006).Teaching and Learning Mathematical modelling with Technology. National Institute of Education Nanyang Technological University 1, Nanyang Walk, Singapore. 637616.

Novriansyah,T. (2012). Pengaruh Pembelajaran Berbasis masalah terhadap Kemampuan Pemodelan matematika di Kelas VII SMP Negeri 18 palembang. Skripsi. Inderalaya : FKIP Unsri. 
Peker, M. (2009). Pre-Service Teachers' Teaching Anxiety about Mathematics and Their Learning Styles. Eurasia Journal of Mathematics, Science, \& Technology Eductaion. 5 (4), 335-345.

Pradeep,R. (2011). A Study of Mathematics Anxiety Amongst Primary Pre-service Teachers enrolled in a Dutch Teacher Training Program. Tesis. Universiteit Van Amsterdam.

Rusman.(2013). Model-model Pembelajaran. Jakarta: PT.Raja Grafindo Persada.

Rusmono \& Yusro,M. (2009). Pengaruh Strategi Pembelajaran Dan Kecemasan Terhadap Hasil Belajar Matematika. Seminar Internasional, ISSN 1907-2066. Peran LPTK Dalam Pengembangan Pendidikan Vokasi di Indonesia

Suryosubroto. 2002. Proses Belajar Mengajar di Sekolah. Jakarta: PT Rineka Cipta.

The Condition of Education.(2003). U.S. Department of Education Institute of Education ciences NCES 2003-067.

Wahyudin. (2010). Monograf: Kecemasan Matematika. Bandung: Program Studi Pendidikan Matematika SPS UPI.

Yosef,L.G. Mimpi Buruk + Ketegangan $=$ Belajar Matematika. http://www.kabarindonesia.com. Diakses pada tanggal 25 Januari 2016.

Yuliani,R.(2007). Peran Teori Belajar dalam Pembelajaran Matematika. Wawasan Kependidikan, Vol:2, 88-98.FKIP UMP.

Zakaria, E., \& Nordin, N. M. (2008). The Effects of Mathematics Anxiety on Matriculation Student as Related to Motivation and Achievement. Eurasia Journal of Mathematics, Science, \& Technology Eductaion. 4 (1), 27-30. 